\title{
Inability to Irrigate
}

National Cancer Institute

\section{Source}

National Cancer Institute. Inability to Irrigate. NCI Thesaurus. Code C63105.

Failure (=complete nonperformance) with regard to the intended function of irrig ation. 